\title{
2. Skilled migration in the literature: what we know, what we think we know, and why it matters to know the difference
}

\section{Elisabetta Gentile*}

\section{INTRODUCTION}

The global importance of international migration cannot be underestimated. In 2015, 3.3\% of the world's population lived outside their country of origin. ${ }^{1}$ Yet, many misconceptions about migration persist in both the literature and policy dialogue. Large-scale surveys conducted in 2018 - in Germany, France, Italy, Sweden, the United Kingdom (UK), and the United States (US) - found strikingly large biases in the host's perceptions of the number and characteristics of immigrants. For example, in all countries, respondents greatly overestimate the total number of immigrants. They think immigrants are, among other things, culturally more distant, less educated, more unemployed, poorer, and more reliant on government transfers than is the case (Alesina et al. 2018). Migrants are also believed to be less skilled than those who stayed in the source country, a phenomenon that researchers call "negative selection." 2

In reality, international migration has been increasingly restricted since the end of World War II, to the point that individuals who are not skilled - in fact, exceptionally skilled - find it difficult to seek legal employment in other countries. In fact, the increasing restrictions and regulations imposed on global migrant flows, in turn, have fueled growth in undocumented migration (Massey et al. 2005). Several Organisation for Economic Co-operation and Development (OECD) members use points-based systems that require immigrants to meet a specific set of criteria (e.g., language proficiency, educational attainment, professional or trade licenses/certifications, age, and financial situation) before they are even considered for admission. ${ }^{3}$ Host countries then choose among eligible applicants based on their labor and economic needs. 
The data confirm that emigrants globally are positively selected in terms of schooling (Hanson 2010), due to both their own circumstances and the host countries' migration systems. ${ }^{4}$ That already calls into question two salient features of neoclassical migration models: (i) the traditional push-pull approach, as host countries have long stopped "pulling" and are now actively restricting new immigration and expelling undocumented workers; and (ii) a focus on raw labor, when data show human capital is more important-moreover, raw labor is treated as homogenous, when worker characteristics such as education, ethnicity, gender, and location are important determinants of migration.

Figure 2.1 shows the "desired emigration rate" of the population over age 25 in eight Association of Southeast Asian (ASEAN) economies for 2010. The desired emigration rate - derived by Docquier et al. (2014) using Gallup World Poll data - is defined as the share of native non-migrants who say they would be willing to emigrate (permanently or temporarily) if they had the opportunity, but remain in their country of origin. ${ }^{5}$ This is broken down into two groups: those with a college degree (college-educated), and those without

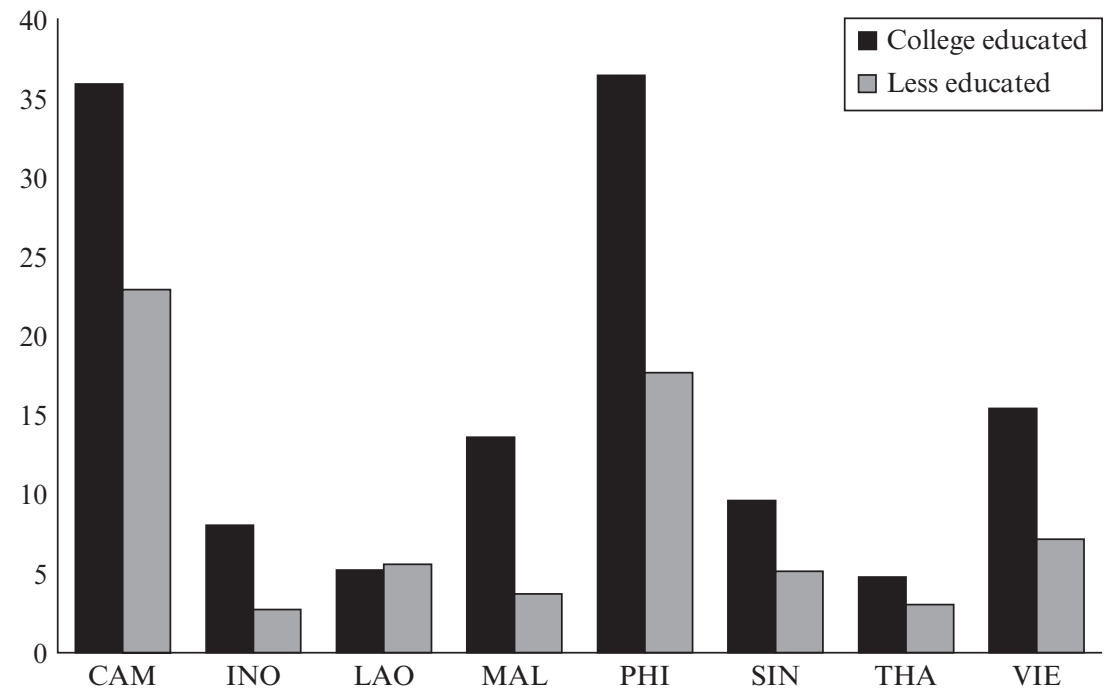

Note: $\quad \mathrm{CAM}=$ Cambodia $; \mathrm{INO}=$ Indonesia $; \mathrm{LAO}=$ Lao People's Democratic Republic; MAL $=$ Malaysia $;$ PHI $=$ Philippines; SIN $=$ Singapore THA $=$ Thailand VIE $=$ Viet Nam.

Source: Docquier et al. (2014) using Gallup World Poll data.

Figure 2.1 Desired emigration rates of college-educated and less-educated individuals by country of origin (2010) 
(less-educated). We can see that the desired emigration rate is much higherin fact, twice as high - for the college-educated than for the less-educated.

Looking at actual migration, Chapter 1 shows that during 1995-2015, ASEAN almost trebled its total migrant population-from 3.7 million in 1995 to 9.9 million in 2015. This reflects the economic rise of the so-called "tiger cubs" of Malaysia and Thailand, ${ }^{6}$ as well as the sustained growth in Singapore and Brunei Darussalam. The share of intra-ASEAN migrants to the total migrant population has grown steadily-from just below $58 \%$ in 1995 to $70 \%$ in 2015 . However, only a small if growing fraction of intraregional migrants are high-skilled workers (Batalova et al. 2017): OECD members and the Gulf countries continue to exert a powerful pull on ASEAN professionals. ${ }^{7}$

Researchers use proxies to operationalize the concept of "skilled migrant" - which varies across countries and over time - and apply different methodologies. For example, both Card (2001) and Borjas use US Census data to investigate the impact of immigrant inflows on the labor markets of their native counterparts. However, Card compares the wage and employment opportunities of native workers in areas with high versus low immigrant concentrations, and divides workers into six different broad occupational groups with increasing skill level. ${ }^{8}$ Borjas (2003), on the other hand, utilizes national data and sorts workers into skill groups created by interacting four education groups with eight experience groups defined in five-year intervals. Therefore, when comparing findings from the two studies, it is important to be aware not only of differences in data and methodology, but also of the way "skill" is defined and measured.

This chapter interprets the facts and trends discussed in Chapter 1 through the lens of the existing academic literature on migration. Its purpose is not to survey the entire body of relevant literature ${ }^{9}$ - which would require a book on its own - but rather to review those works that provide useful insights for skilled labor mobility in the ASEAN Economic Community. This is particularly important given the scarcity of highquality data on international labor flows. We are living through a nationalist resurgence on a global scale. Now, more than ever, public policy must be guided by empirical realities rather than fear of the unknown. This chapter aims to be a step in that direction.

\section{EXPLAINING THE PATTERNS OF SKILLED MIGRATION}

In 1986, the failure of an O-ring caused the space shuttle Challenger to explode just 73 seconds after launch. A simple donut-shaped rubber ring 
brought down a $\$ 196$ billion orbiter built using 2.5 million parts and assembled by hundreds of teams.

One might wonder what a malfunctioning seal has to do with skilled labor migration in ASEAN: rather a lot, as it turns out. Kremer (1993) used the O-ring metaphor to put forward an economic theory that has powerful implications, among other things, for global migration patterns.

Kremer proposed a production function in which production consists of a series of tasks, all of which must be completed correctly for the final product to pass quality controls. Each task can be completed at a different level of "skill" - where skill is defined as the probability that a worker will successfully complete a task, and the value of each worker's efforts depends on all other workers' skill. Contrary to the neoclassical approach, this production function does not allow quantity to be substituted for quality: going back to the space shuttle example, substituting an excellent engineer with two or more mediocre ones will negatively impact the quality of the final product. Conversely, high-skilled workers complement each other, giving rise to increasing returns to skills and even higher productivity. It is then easy to see how, under this production function, even small differences in worker skills lead to large differences in wages and output.

In light of Kremer's model, skilled workers from ASEAN prefer to migrate outside the region because, even with similar individual skills, they will be far more productive once matched up with the skilled labor force of the host country. This conclusion contradicts the neoclassical models of trade and growth. A standard neoclassical framework would predict negative selection of emigrants - as human capital has a higher marginal product (and therefore a higher return) in developing economies, where it is relatively scarce.

Borjas (1987) developed a version of the famous neoclassical model of migration known as the Roy model (Roy 1951), in which the relative payoff for skills across a given source-host country pair determines the skill composition of the migrant flow: if the return to skill is higher in the host economy than the source country, it will attract migrants from the upper tail of the skill distribution, leading to positive selection. Conversely, if the source country offers a higher payoff, then there will be negative selection because the host economy will attract individuals from the lower tail of the skill distribution.

Borjas tested his model by regressing the earnings of immigrants in the US on measures of the source country's income inequality, intended as a proxy for the rate of return to skills. He found a negative correlation and concluded that in countries with low average wages and high wage inequality - still the case in much of the developing world-there is negative selection of emigrants. However, the correlation becomes positive 
and insignificant when controlling for gross national product (GNP) per capita, which comes in positive and significant. Borjas interpreted that to mean that the higher the GNP per capita in the source country, the more it resembles the host economy and the greater the skill of the immigrant flow.

Borjas (1987) was very influential, with the "negative selection hypothesis" gaining ground in public opinion as well as academia. ${ }^{10}$ More recently, Grogger and Hanson proposed an alternative formulation of the Roy model. They evaluate migrant selection in terms of skill by comparing the probability of emigrating for those with a college education relative to those with a primary education. In this framework, there is positive selection if the absolute wage difference between the source and destination, net of skillvarying migration costs, is greater for high-skilled workers. In addition, there is positive sorting if emigrants from a given source country, say Indonesia, sort themselves across destinations by skill according to the rewards-to-skill in various destinations. If the (net) rewards-to-skill are higher in Singapore than in Malaysia, then Singapore will receive a higher-skill mix of emigrants from Indonesia than Malaysia. In other words, "higher skill-related wage differences should give destination countries an advantage in competing for skilled immigrants" (Grogger and Hanson 2011).

The data show that in 2015, more than 1 million Indonesian workers resided in Malaysia, where the average monthly wage was 3.5 times that of Indonesia, while there were only 163,000 Indonesian citizens working in Singapore, although the average monthly wage there was over 20 times that of Indonesia. ${ }^{11}$ If wages were the only driver of migrant flows, we would expect all Indonesian workers to flock to Singapore. More likely, Indonesian workers who choose to migrate to Singapore are inherently different from those who choose to migrate to Malaysia in that they have different characteristics or preferences, or both.

The model was tested on the population of immigrants 25 years and older by source economy and education level in a sample of OECD countries as of 2000. The results show that, indeed, for a given source-host country pair, the larger the skill-related difference in earnings, the more one finds educated migrants (relative to non-migrants). In addition, the relative stock of higher-educated migrants in a host economy increases with the earnings difference between high- and low-skilled workers.

Why do Borjas (1987) and Grogger and Hanson reach such diametrically opposed conclusions? Borjas models utility in log-linear form, which explains migration in terms of relative wage differences. One limitation of this approach is that, given the strong curvature of the log-linear utility function, decreasing marginal returns to income matter equally, regardless of how large the absolute difference in income is. In the top panel of Figure 2.2, we can see that doubling the wage from 10 to 20 units or from 


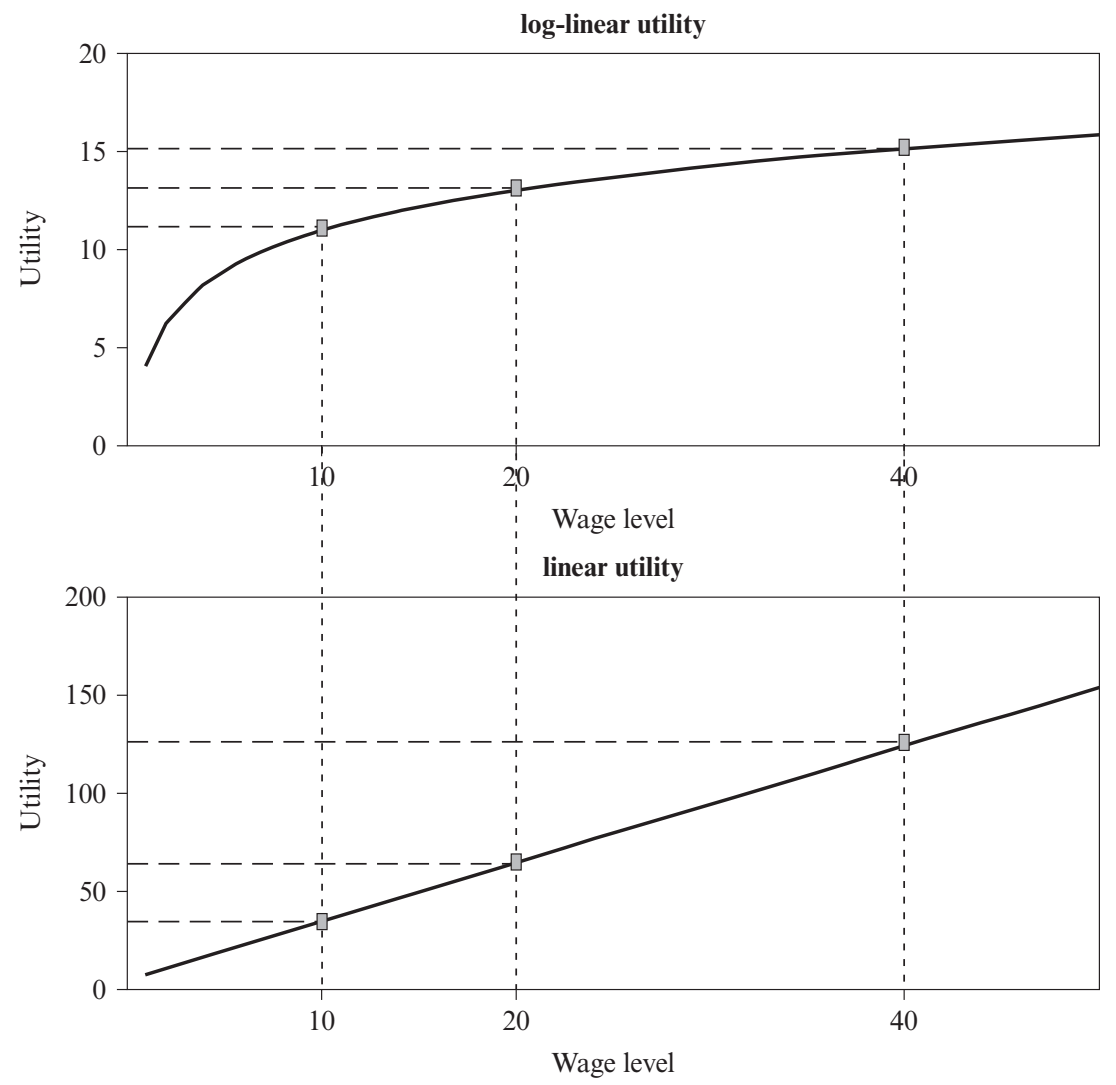

Source: Author's calculation.

Figure 2.2 The implications of log-linear versus linear utility

20 to 40 units yields the same increase in utility, represented by the two segments marked on the vertical axis. Grogger and Hanson, on the other hand, model utility in linear form, which explains migration in terms of absolute wage differences. The bottom panel of Figure 2.2 shows that because the change in wage from 20 to 40 units is double that from 10 to 20 units, then the change in utility is also doubled.

Note that linear utility is also restrictive, as it implies that decreasing marginal returns to income are never an issue. However, given the very large income differences that exist between source and destination countries, linear utility is a better fit for the data, suggesting that migration responds to absolute, not relative, rewards-to-skill. 
Despite the serious data limitations discussed in Chapter 1, it is widely agreed that emigration from ASEAN countries to non-ASEAN countries involves more skilled workers than intra-ASEAN migration, whereas most intra-ASEAN migration involves low-skilled workers (Ruhs 2016). Therefore, Grogger and Hanson's framework, along with Kremer's O-ring theory, provides a convincing explanation as to why skilled workers from ASEAN have historically preferred to migrate outside the region, especially to OECD countries.

A widespread concern is whether source countries will manage to achieve their full economic potential, which crucially depends on their ability to provide a sufficiently large number of skilled workers to meet the demand from high-growth sectors. For example, the Master Plan on ASEAN Connectivity 2025 (ASEAN 2016) focuses on digital technologies - particularly mobile internet, big data, cloud technology, the internet of things, automation of knowledge work, and the Social-MobileAnalytics-Cloud (SMAC) - to unleash growth in the region (see Chapter 10). But the success of this strategy rides on a labor force with the right skills to make it happen. Indeed, "almost all of ASEAN member states report shortages of skilled labor, particularly in the priority professions identified [. . .] for the free movement of labor" (Parpart 2016). Section 3 will address this issue by discussing the controversial brain drain.

A second question is whether the outflow of human capital can be reversed, and there is positive evidence that it can. In some rapidly growing developing Asian economies, limited supply of educated and technically trained workers has led to inflows of human capital in a manner predicted by neoclassical theory. Singapore's meteoric rise from a "malarial fishing village" (Bueno 2013) to the third wealthiest country in the world (in per capita gross domestic product [GDP]) was aided by a sustained influx of foreign human capital.

Another example was Indonesia's accelerated industrialization in the 1980s, which stemmed from a government effort to open the economy and diversify from petroleum to manufactured exports (Goeltom 2007, 489506). This "created a demand for specialists in engineering, management, finance, and other professions that could not be met locally, yielding rising returns to human capital that attracted skilled migrants from Australia, the Philippines, Europe and India, despite a 40\% underemployment rate among Indonesian(s)" (Massey et al. 2005). These examples suggest that economic opportunity, along with the "right" policies, can help ASEAN countries not only retain more home-grown skilled workers, but also attract returning migrants and foreign talent. 


\section{THE MOST PERSISTENT MYTHS: "BRAIN DRAIN" AND "BRAIN GAIN"}

As mentioned, from the mid-1900s, increasingly higher educational and skill thresholds were needed to migrate to developed countries. And many of those who managed to leave poorer countries to make a better living in advanced economies were the very ones developing countries could least afford to lose. This brain drain phenomenon has inspired a large body of academic and policy research. The early literature was based on observations from the first great post-colonial surge of skilled labor migration. The second surge - roughly 50 years later — was aided by the "third industrial revolution" and inspired a new wave of brain drain research, both theoretical and empirical. ${ }^{12}$

The early models (Bhagwati and Hamada 1974 is perhaps the most widely used) have had a long-lasting impact on the way we typically think about the brain drain. These are general equilibrium frameworks that model the source country labor market, whereas demand for emigrants is exogenously determined. They commonly assume a public subsidy to education, along with wage rigidity. Under these assumptions, they generally find that emigration tends to lower output and employment in sending countries, and that the losses accrued to different sectors depends on the structure of the relative wage and pre-migration employment levels across sectors.

It is intuitive to see how this class of models - meant to underscore the potential risks to developing economies from massive emigration of skilled workers - could lead to a simplistic zero-sum interpretation of the brain drain, where the source country has everything to lose and the host country everything to gain. In fact, gains and losses accrue on both sides, and the net effect can be positive for both sending and receiving countries.

\subsection{Sending Countries}

It is a commonly held view that skilled workers embody an investment their country made (i.e., the public subsidy to education). And when they emigrate, another country reaps the return on that investment. Desai et al. (2009), for example, estimated an annual loss of $2.5 \%$ of fiscal revenue from high-skill emigration in India. This led to calls for a tax on the income earned by skilled migrants in the destination country to the benefit of the source country (Bhagwati 1976).

It is worth mentioning that, at this point in time, the private sector's role in training the labor force was growing steadily, especially in Asia and the Pacific - where the lack of adequate government funding for education 
and training led students to private providers. The private sector also responds faster to changing skill demands: for example, during the boom in demand for nursing degrees in the Philippines in the 2000s, the rapid expansion of nursing programs was largely driven by the private sector (Abarcar and Theoharides 2017).

Even if education and training were $100 \%$ publicly funded in source countries, setting negative incentives to migration, supposedly to motivate prospective migrants to stay, does not guarantee the education subsidy will not be lost. Skilled workers often cannot find positions to match their skills at home, as labor markets in many developing countries are characterized by unemployment, underemployment, and overqualification. Cronyism and ethnic fractionalization exacerbate the situation when access to already scarce employment and career development opportunities is not determined solely by merit.

Finally, Kremer's O-ring production function explains why the most highly skilled must work with each other - and have access to specialized services and high-quality equipment - to maximize their productivity (Felipe 2010, Chapter 15). Emigration is often the only way to fulfill these conditions.

In sum, these considerations show that skilled emigration is only a proximate cause of the lost subsidy; the ultimate causes are "a series of policy decisions by the government, as well as the range of factors that caused the migration choice" (Clemens 2009). Therefore, a migration tax such as the one proposed by Bhagwati would penalize migrants for what is substantially government failure.

Source countries can still benefit from skilled emigration, even when skill acquisition is publicly funded. Remittances are the most immediate way. Remittances improve the well-being of family members left behind and boost the economies of source countries through a variety of channels (see, for example, Dinkelman and Mariotti 2016; Theoharides 2018; Yang 2008). One popular misconception is that skilled migrants either do not remit or remit less, which is motivated by other misconceptions, for example: that skilled emigrants tend to spend longer periods abroad; that they are more likely to be joined by their families in host countries, and become permanent migrants who gradually lose ties with their country of origin; that quality education and specialized training in developing economies are the prerogative of affluent families, which do not require support from relatives abroad.

Two cross-country studies (Faini 2007; Niimi et al. 2008) relate the total remittances received by a given country in a given year to the share of emigrants with tertiary education. They find that remittances are positively correlated to the source country's total emigrant stock, and 
negatively correlated to the share of emigrants with tertiary education. Although they interpret their results to mean that "skilled migrants do remit less" (Niimi et al. 2008), in fact they only say that countries that send a larger share of highly skilled migrants receive less in remittances than countries that send fewer skilled migrants. This negative correlation may have nothing to do with a skilled migrant's propensity to remit, but rather has structural causes.

Bollard et al. (2011) assembled an impressive micro-level database on remitting behavior - comprising data on 33,000 immigrants from developing countries from 14 surveys in 11 OECD host countries - which allowed them to study the association between a migrant's education level and their remitting behavior. They found a mixed association between education and remittances at the extensive margin (i.e., whether more-educated individuals are more likely to remit), and a strong positive relationship at the intensive margin (i.e., whether they send more when they do remit). Combining both the extensive and intensive margins showed that moreeducated migrants do remit significantly more.

Contrary to the traditional view, the gains to developing countries from skilled emigration extend beyond remittances, for example to human capital formation. Brain drain "pessimists" tend to recognize return migration as the only way through which source countries can reap human capital gains, i.e., new skills acquired abroad made available to the home country. Consequently, they tend to draw a distinction between short- and long-term migration whereby only short-term migration benefits human capital formation.

The so-called "beneficial brain drain"13 literature overcomes this limited perspective by introducing two crucial elements:

1. Human capital accumulation is endogenous. Because people respond to incentives, higher prospective returns to human capital in a foreign country may induce workers to acquire more through education and training.

2. Successful emigration is not a certainty. A fraction of those who invest in human capital to improve their odds of success will fail to secure employment abroad.

Stark et al. (1998) present a simple model in which individuals live for two periods. In the first, they split their time between work and human capital formation. In the second, they enjoy the earnings commensurate to the human capital they accumulated during the first period. They solve the model for the optimal level of human capital formation in the closed economy, and then introduce the probability of migration to a country that 
offers much higher returns to education. They find that the optimal level of human capital formation is higher than in the absence of an opportunity to migrate. In other words, the home country can end up with a higher stock of human capital when migration is an option for high-skilled members of its workforce.

Mountford (1997) examines the effects of migration on income distribution and human capital accumulation using a model that divides an individual's life for three periods. In the first, an individual wants to consume and invest resources in human capital accumulation but must borrow from the capital market to do so. During the second, individuals work, repay their first period debt, consume, and save for their third period, when they are retired and use their savings to consume.

Mountford's model has two key features. First, productivity in the economy is dependent on the average level of human capital of the eldest generation; and, second, the greater the human capital accumulation of an individual's parent, the easier it is for that individual to accumulate human capital. Consequently, the chance of emigrating to a higher-wage economy can increase human capital accumulation both in the short and long run. In the short run, individuals are incentivized to accumulate more human capital because it allows them to earn a higher return, like in Stark et al. (1998). But emigration can also affect the long-run income distribution in the economy by creating a greater proportion of individuals with high levels of human capital - and "it is this long-run channel that is potentially the most powerful and most long-lasting" (Mountford 1997). Therefore, both temporary and permanent emigration of skilled labor can have permanently beneficial effects on economic growth if they alter the long-run income distribution of the economy.

A host of empirical studies support the theoretical findings in Stark et al. (1998) and Mountford (1997). Chand and Clemens (2008) used the unexpected and largely bloodless coup d'état that took place in Fiji in 1987 - which triggered one of the largest, most rapid exoduses of skilled workers from any developing country in recent history-to study whether skilled emigration depletes local human capital. The new government enacted a series of economic measures that many Fijians of South Asian descent (some 50\% of Fiji's population were considered "Indo-Fijians") saw as permanently harming their prospects in the country. Therefore, young Indo-Fijians began to quickly and massively invest in higher education to increase their odds of moving to other Commonwealth countries with skill-selective, points-based immigration systems (i.e., Australia, New Zealand, and Canada). The study found this increase in investment was large enough to raise Fiji's stock of human capital, net of the massive departures of skilled workers. 
Shrestha exploits the change in recruitment policy for Nepalese men in the British Army. Before 1993, there were no minimum education requirements; but from 1993 onward, candidates had to have a minimum eight years of education and pass written tests in math and English. The study finds that the policy change raised human capital accumulation within Nepal, with a significant increase in those completing secondary education. Since the number of recruits - and therefore emigrants to the UK - remained constant over time, the educational levels of those who remained in Nepal increased, "as evidenced by improvements in job quality, including a shift to formal, salaried employment, as well as higher earnings in the domestic labor market" (Shrestha 2017).

Abarcar and Theoharides (2017) use changes in demand for nurses due to US immigration policy to identify the effect that large-scale emigration of Filipino nurses had on tertiary enrollment and graduation in nursing programs in the Philippines. In 2000, the US dramatically expanded the availability of visas for migrant nurses and their families. Then in 2007, it suddenly imposed restrictions on the number of these visas issued. Between 2001 and 2006, enrollment in nursing programs in the Philippines rose from 90,000 to over 400,000 , and the number of nursing graduates grew from 9,000 to 70,000 . The magnitude of the increase in nursing degrees was such that not all the additional nurses could migrate. After 2007, when the visas for nurses dropped, nursing enrollment and graduation declined.

Khanna and Morales (2017) use the mid-1990s' US internet boomwhich led to an increase in demand for computer scientists (due to skill-selective US immigration policy) - to identify the effect large-scale emigration of India's computer scientists have on human capital investment decisions of workers and students (along with the overall performance of the information technology [IT] sector, both in India and the US). They calibrate their theoretical model of firm production, trade, and the forward-looking decision of workers and students to accumulate human capital. The results show that the prospect of migration induced Indians to switch to computer science (CS) occupations, increasing India's CS workforce and raising India's overall IT output by $5 \%$. In the US, on the other hand, workers switched to non-CS occupations, reducing the US native CS workforce by $9 \%$ (see Section 3.2 for a discussion of this phenomenon, known as the crowding-out effect). Consumers in both countries benefited from larger overall IT output, leading to lower prices for IT products, and the combined income of both countries rose by $0.36 \%$ because of this flow of CS professionals from India to the US. The CS workers unsuccessful in migrating to the US joined the rapidly growing IT sector in India, and by the early 2000s many workers returned to India after their visas expired with newly acquired knowhow and connections. 
This also brought the US-led boom to India, and by the mid-2000s India had surpassed the US in software exports.

The three examples from Fiji, Nepal, and the Philippines demonstrate that demand for skilled migrants from abroad can lead to human capital formation in the domestic economy by increasing the returns on education. That is because the prospect of migration will induce more workers to invest in human capital, and only a fraction of those workers will obtain migrant visas. The example from India goes further, illustrating the importance of diaspora networks in spurring innovation and growth in the source country. Note that skilled migrants do not have to return to their home countries to play this crucial role. Rather, with their presence in the host country, "they can serve as 'bridges' by providing access to markets, sources of investment, and expertise" (Kuznetsov and Sabel 2006).

\subsection{Receiving Countries}

The impact of skilled immigration on receiving countries is no less controversial. For example, one study says that "[if] lower-skilled migrants are sometimes said to take jobs that natives do not want, high-skilled migrants are usually employed in the types of jobs that many would prefer go to natives" (Regets 2001). It is a commonly held view that skilled immigrants depress labor market opportunities for their native counterparts, the so-called "crowding-out effect." Especially in countries where tertiary students pay high tuition fees, or in professions for which training is substantially provided by the private sector, skilled immigrants are viewed as "unfair competition" - as they supposedly enjoy cheaper or heavily subsidized education in their home countries. This thinking is flawed for two reasons: first, it ignores the cost of migration and other socioeconomic factors in sending countries; and, second, it considers only the direct impact of skilled immigrants on their native counterparts, thus ignoring indirect effects on the broader economy.

Unfortunately, available empirical evidence in this area is scarce, as opposed to abundant literature examining the effects of lower-skill immigrants on opportunities for lower-skill natives. Furthermore, the little evidence available is overwhelmingly focused on the US.

Early work by Grubel and Scott expresses the perception of international migration at that time: an accounting exercise in which one country "gains" brains that are "drained" out of another. They used data from the US National Science Foundation containing the numbers of scientists and engineers who emigrated to the US between 1949 and 1961, and estimated what it would have cost to bring a native American to the level of education held by the average immigrant at the time of his arrival. 
They concluded that the human-capital value of these migrants was "of negligible importance relative to the size of the US stock of human and material wealth and the capacity to produce current output" (Grubel and Scott 1966). In the light of their findings, it was not surprising that the brain gain had not become a major policy issue for the US.

But, not only has the flow of skilled migrants into the US grown significantly since then, but the way we think about the impact of skilled immigration on the host economy has also substantially evolved. As hinted above, it is useful to think of the impact as having three dimensions: first, how skilled immigrants affect their native counterparts; second, their effect on the broader economy; and, third, their effect on the global economy.

Chiswick (2011) proposes a simple theoretical approach - based on the neoclassical aggregate production function - where the factors of production are capital, high-skill labor, and low-skill labor, and they are combined to produce output based on available technology. The key assumption is that high-skill immigrants are perfect substitutes for high-skill natives, whereas they complement low-skill workers and physical capital. Because of two well-known properties of the neoclassical production function-(i) factor complementarity (a combination of all three factors of production is needed to produce output) and (ii) diminishing marginal product, ${ }^{14}$ increasing the supply of high-skill workers through immigration (holding the supply of other factors constant) will reduce the earnings of high-skill workers while simultaneously increasing the earnings of low-skill workers and the returns to capital. Similarly, increasing the supply of low-skill workers will benefit high-skill workers and owners of capital, and hurt low-skill workers. Note that in this framework the broader economy unambiguously benefits from increasing the supply of any of the three factors of production through an increase in aggregate output.

Borjas (2003) tested the neoclassical approach using US Census data for 1960-2000. He estimated the labor market impact of immigration in the US by partitioning workers among imperfectly substitutable groups (by education and experience) while assuming perfect substitution of native and foreign-born workers within each group. He found that immigration reduced the wage and labor supply of competing native workers, even after accounting for the beneficial complementarity effects between high-skill and low-skill workers. During the period, the immigrant influx reduced the wage of the average native worker by $3.2 \%$ and the wage of college graduates by $4.9 \%$. However, by his own admission, Borjas ignored the long-run capital adjustments induced by immigration, as well as the role played by capitalskill complementarities, and the possibility that high-skill immigrationespecially in science, technology, engineering, and mathematics (STEM) fields - is an important engine for endogenous technological change. 
Ottaviano and Peri (2005) build on this model in two substantial ways. First, they estimate the actual elasticities of substitution between native and foreign-born US workers in the same skill group. They find that foreign-born workers within a skill group are not perfect substitutes for US-born workers. In particular, native-born college graduates are the hardest to substitute with foreign-born college graduates. The intuition behind this finding is that jobs that require higher education tend to also require higher levels of human interaction, where language skills and knowledge of cultural norms are an advantage. Furthermore, US graduates tend to receive a US-specific education, whereas foreign graduates have to adapt their skills to US standards.

Their second contribution is to treat the accumulation of physical capital as endogenously driven by market forces that equalize real returns to capital in the long run-whereas Borjas assumed a fixed capital stock. Like Borjas, Ottaviano and Peri find negative wage elasticities to the supply of foreign workers in the same skill group. However, when they embed them into a production function that accounts for substitution and complementarity effects, they find a $2.7 \%$ increase of the average wage of US-born workers because of immigration, with US-born college graduates seeing a $3.5 \%$ increase.

Because the US is a large economy - and immigrants tend to concentrate in a few geographical areas - we cannot exclude the possibility that factor price equalization with a large unaffected geographical area may "dilute" the local effects of immigration. A small economy, on the other hand, is closer to the single labor market posited by neoclassical economic theory.

Friedberg (2001) used the 1989 lifting of travel restrictions in the former Soviet Union - which triggered a mass migration of Soviet Jews and their non-Jewish relatives and spouses to Israel - to study the effect of immigration on employment and earnings growth of native Israelis. She found a large positive effect of immigration on the wage growth of native Israelis: between 1989 and 1994, a 10\% increase in employment due to Soviet immigration led to a $7.4 \%$ rise in hourly earnings of Israelis in the occupation. In addition, in high-skill occupations, for every $10 \%$ increase in occupational employment due to immigration, native wages rose by about $3 \%$. Furthermore, Friedberg did not find any evidence of a displacement effect of immigrants on natives. Overall, the results point to the possibility of complementarity between immigrants and native workers.

One potential issue with Friedberg's findings is that the boom in Soviet immigration happened just as Israel's high-tech sector was booming, so the resulting increase in demand for high-skill workers could have offset the latent depressing effect of immigration on wages. However, Soviet 
immigration is often indicated as a causal factor in the expansion of Israel's high-tech sector (Stone 1999).

We can conclude from these studies that the impact of skilled migrants on opportunities for skilled natives depends on the degree of substitutability between the two groups, which is likely to vary by sector, and even by subsector. Therefore, high substitutability between the two groups as theorized by Chiswick can be considered a worst-case scenario for skilled natives. Here, the increase in skilled labor supply through immigration leads to a decrease in earnings for natives, which in turn results in decreased incentives for natives to invest in human capital accumulation. The mechanism is symmetric to the one theorized by Stark et al. (1998) and Mountford (1997) for human capital accumulation in source countries, where prospective migration is a positive incentive for human capital accumulation (see Section 3.1). However, this neoclassical approach also assumes that higher-skill workers complement both lower-skill workers and physical capital - meaning that high-skill migrants can generate both demand for lower-skill labor and new capital investment. That, in turn, would increase demand for higher-skill workers, thus moderating the negative incentive for human capital investment in natives.

Another concern related to the influx of skilled migrants is that an increase in the enrollment of foreign students in advanced academic and training programs means fewer places for natives. However, this reasoning assumes that higher-education and training institutions have a fixed number of slots to assign, and that for every foreign applicant there is a native with the same skill level who gets crowded out. The reality is that institutions have a degree of flexibility on the number of students they admit, and when they can choose among the best of both foreign and native applicants, they raise the bar for the entire program's benefit. Furthermore, public universities in countries like the US, the UK, and Australia are increasingly reliant on the revenue provided by international students (in the face of decreasing public funding), while private universities seek international students to bolster their position in the face of increased international competition.

In 2011, growing unease among Singaporeans over foreign students "taking the place of locals" led to the government placing a cap on enrollment of international students in local universities (Davie 2014). In their call for the Singaporean government to reverse the policy, Seah and Png (2018) point out that international students, particularly those paying full tuition fees, not only help support university budgets in the face of a shrinking population, but also benefit local students and Singapore in general. They argue that international students bring diverse perspectives to class discussions and allow local students to build international networks 
that become a gateway to information on employment and business opportunities abroad.

Critics also argue that foreign students who remain in the host country after graduation compete for jobs with their local peers. In his study of doctoral recipients in the US between 1968 and 2000, Borjas (2005) shows that a foreign student influx into a particular doctoral field at a particular time had a significant and adverse effect on the earnings of doctorates in that field who graduated at roughly the same time: a $10 \%$ immigrationinduced increase in the supply of doctorates lowered the wage of competing workers by about $3 \%$.

Conversely, Chellaraj et al. (2008) estimate the impact of international students in the US on innovative activity from 1965 to 2001. They find that the presence of foreign graduate students has a significant and positive impact on both future patent applications and future patents awarded to university and non-university institutions: a 10\% increase in the number of foreign graduate students would raise patent applications by $4.5 \%$, university patent grants by $6.8 \%$, and non-university patent grants by $5.0 \%$. They also find skilled immigration to have a positive, but smaller, impact on patenting.

Skilled immigrants, especially in STEM fields, are highly entrepreneurial. Even as employees, they develop "new techniques, products, markets and inventions, and new ways of using older ideas" (Chiswick 2011). According to the Kauffman Index of Entrepreneurial Activity, in 2016 immigrant entrepreneurs accounted for almost $30 \%$ of all new entrepreneurs in the US, up from $13.3 \%$ in 1996. Immigrants were twice as likely as natives to become entrepreneurs, with the Rate of New Entrepreneurs being 0.52\% for immigrants, compared with $0.26 \%$ for natives (Fairlie et al. 2017).

Especially in OECD countries, a frequent public perception is that migrants receive a disproportionate amount of social benefits in host countries. In fact, the data show that "migrants pay more taxes and make more social contributions than they receive in benefits" (ILO 2015). Skilled immigrants, in particular, tend to have higher wage rates and pay even more taxes and receive less in benefits than low-skilled immigrants. Furthermore, as the simple framework in Chiswick discussed above shows, high-skilled immigration raises the earnings of other factors of production, with the effect of improving the net fiscal balance (taxes minus transfers) of lower-skilled workers as well.

The evidence presented so far indicates several broader economic benefits from an influx of skilled workers (or students): they often have skill profiles in high demand, and they tend to complement, rather than substitute locals. Imposing restrictions on skilled immigrants for the benefit of natives who compete directly with them in a few narrow fields 
is equivalent to "skill protectionism" as, just like trade protectionism, it places the interests of a few above the economy as a whole.

To our knowledge, there is no substantive empirical evidence on the effect of skilled labor mobility on the global economy. However, it is rather intuitive to theorize a positive effect. The emergence of international production networks, and the subsequent fragmentation and specialization in production, leads to "increased employer dependence on scarce or unique skill sets" (Regets 2001). The quality of job matches increases when employers can search across borders, satisfying both employers and workers. This greater efficiency results in higher global GDP. Especially for STEM workers, the creation of international, specialized research and development centers leads to better solutions to challenging problems and reduces duplication in research and development.

\section{OPPORTUNITIES AND CHALLENGES}

The ASEAN region has made significant progress in human capital development, although there are large variations among members-reflecting their different stages of economic development along with differences in policies and practices. Figure 2.3 graphs the four components of the World Economic Forum's 2017 Human Capital Index - capacity, deployment, development, and know-how-for the countries in ASEAN, East Asia, and the Pacific, including global high performers like Australia, Japan, and New Zealand (Zahidi et al. 2017). Across all four dimensions, countries are scored on a scale from 0 (worst) to 100 (best).

Panel A shows the scores for capacity - the level of formal education of the current workforce that results from past educational investment. It includes the percentage of primary, (lower) secondary, and tertiary education, and the proportion of the population that has a basic level of numeracy and literacy. In this dimension, Malaysia, the Philippines, and Singapore perform solidly, while the others remain below full potential.

Panel B shows the scores for deployment - how many people actively participate in the workforce across age groups and gender-important because human capital is substantially enhanced in the workplace. It includes the labor force participation rate, unemployment rate, underemployment rate, and a measure of the gender gap in labor force participation. In this dimension, Cambodia, the Lao People's Democratic Republic (Lao PDR), Myanmar, Thailand, and Viet Nam outperform their neighbors who are top performers in the overall human capital index. However, a high degree of human capital utilization without skill diversification and 


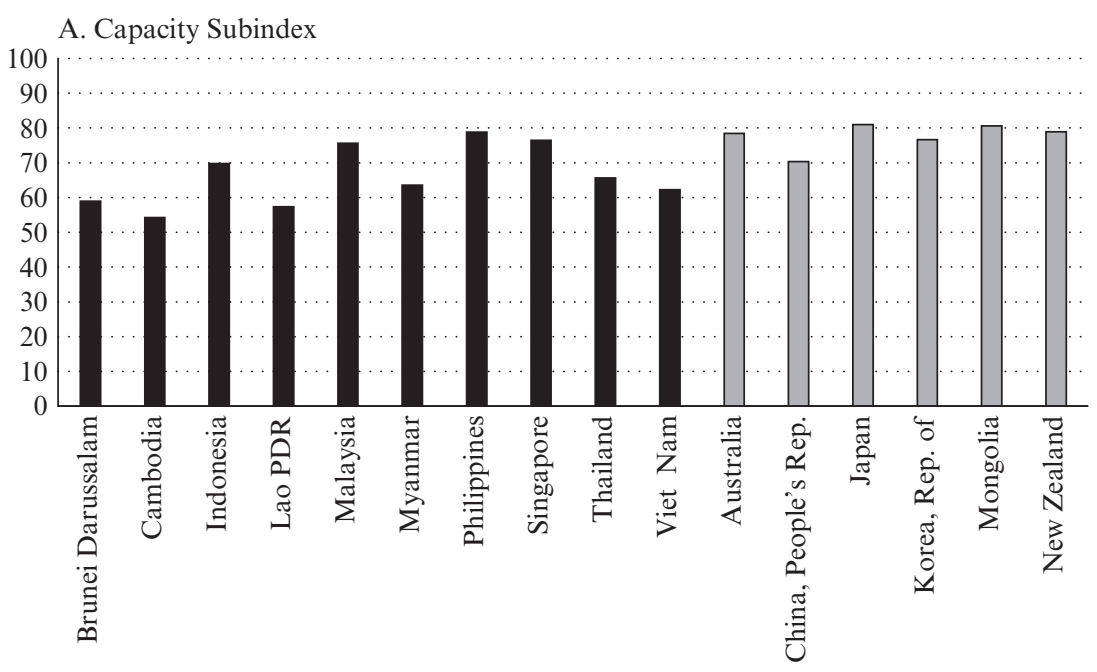

B. Deployment Subindex

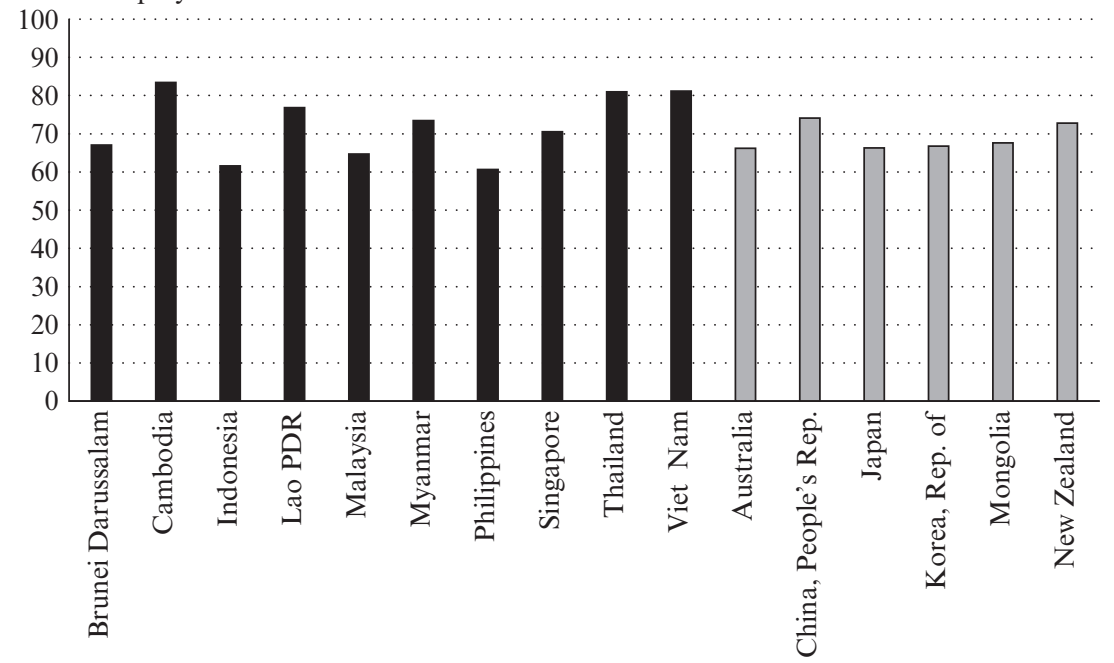

Source: Zahidi et al. (2017).

\section{Figure 2.3 Global Human Capital Index (2017)}

more advanced know-how is not sufficient for a country to optimize its long-term human capital potential.

Panel $\mathrm{C}$ shows scores for development, which measures the formal education of the next-generation workforce and continued upskilling and 
C. Development Subindex

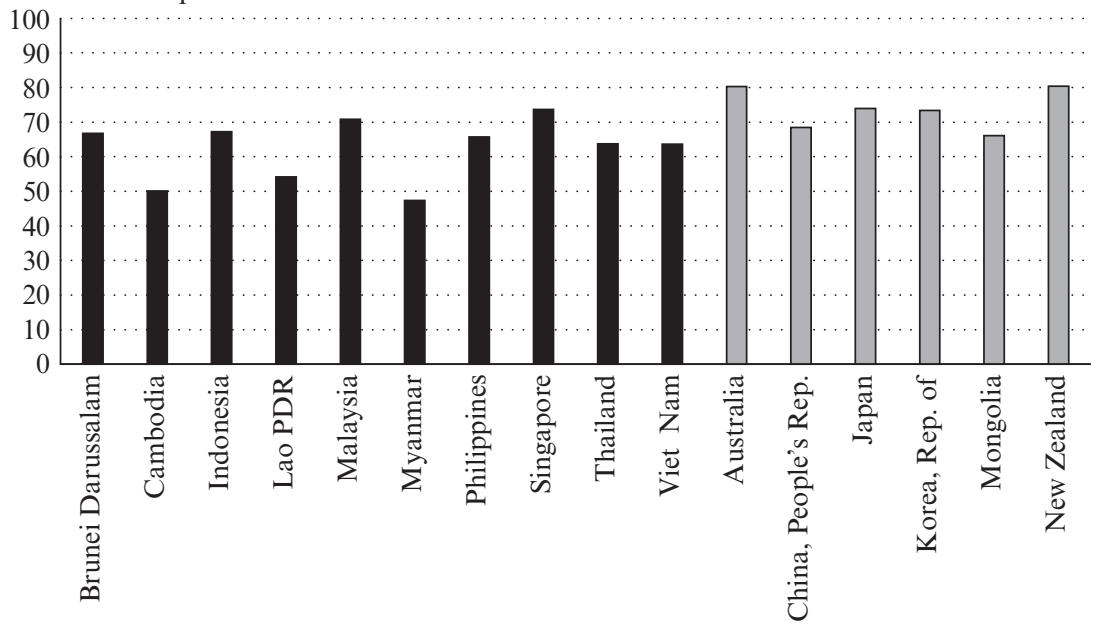

D. Know-How Subindex

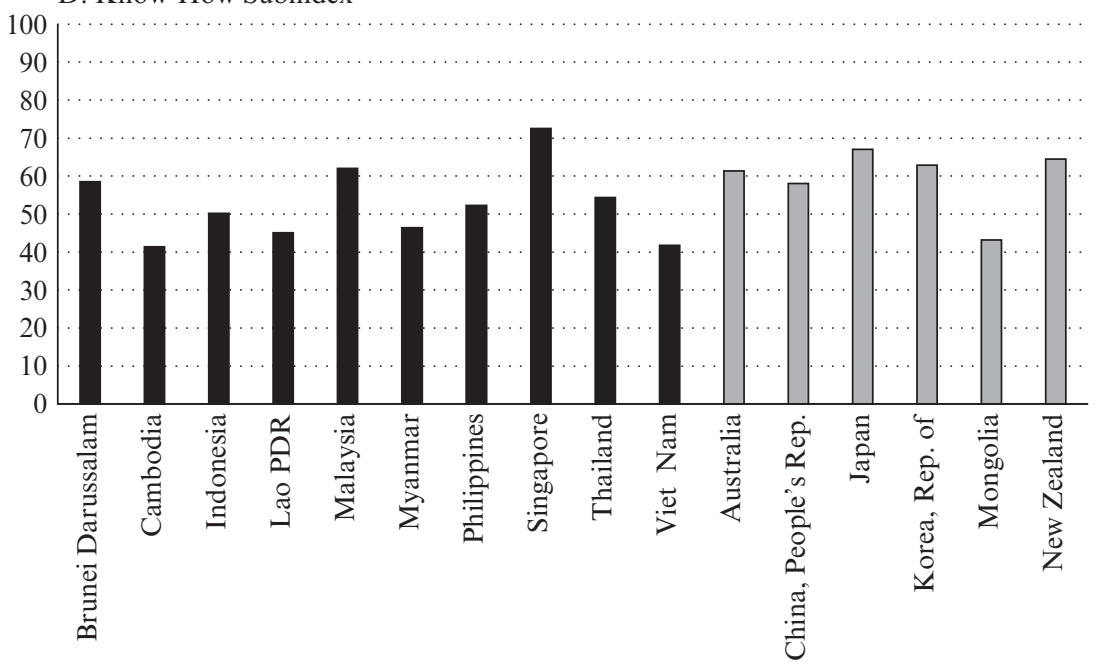

Figure 2.3 (continued)

reskilling of the current workforce. It includes net enrollment rates in primary and secondary schools, gross tertiary enrollment ratios (including both higher education and vocational training), and the gender gap in secondary enrollment for under 15 and 15-24 age groups. It also includes survey-based indicators of the quality of primary education, how well 
the education system meets the needs of a competitive economy, the skill diversity of a country's recent graduates, and a measure of on-the-job training. In this dimension, Singapore and Malaysia perform ahead of the rest of ASEAN; the Lao PDR, Myanmar, and Cambodia significantly underperform their potential; with remaining members showing remarkable progress, especially in the educational attainment of their younger generations (Zahidi et al. 2017).

Finally, Panel D shows the scores for know-how, which represents the breadth and depth of specialized skills used at work. It includes the economic complexity index, which measures the relative complexity of a country's exports, representing the knowledge accumulated in a country's population as expressed in the country's industrial composition. It also includes the high-skill employment share, the medium-skill employment share, and a survey-based measure of employers' difficulty filling job vacancies. In this dimension, Singapore outperforms all countries, Malaysia and Brunei Darussalam perform relatively well, with the others behind.

ASEAN members' performance lends additional support to the argument that an influx of skilled labor can help the host country develop its long-term human capital potential, while deterring the outflow of skilled workers does not help the sending country. That is because it is not enough for source countries to "retain" skilled workers (i.e., capacity). They must be deployed in occupations that match their skill set and have opportunities to develop their skills on the job. Symmetrically, receiving countries would be depriving employers of the skills required to grow certain sectors of the economy, and natives the opportunity to learn those skills from their foreign peers.

The fact that the median age of degree-level workers in ASEAN is the mid-20s-noticeably younger than the entire workforce-means that the region could experience a "demographic dividend" from an increasingly well-educated younger population (World Economic Forum 2016). However, intra-ASEAN mobility of skilled labor is crucial for this dividend to materialize, as it alleviates skill mismatches within the region.

The digital revolution has not only helped workers overcome informational asymmetries; it has also made it easier to stay in touch with families and the communities left behind (see Chapter 10). As a result, skilled workers, especially in STEM fields, "often move from firm to firm, and from country to country, seeking opportunities to advance their skills, as well as apply their skills more fruitfully" (Chiswick 2011). If skilled workers find obstacles to intra-ASEAN mobility, they will simply go elsewhere.

The wave of populism that has taken hold in large parts of Europe, the US, and increasingly Australia has led to downsizing (or ending) programs 
aimed at attracting foreign talent. This is creating a climate of uncertainty among skilled migrants. The ASEAN Economic Community, a dynamic region with a projected growth of over $5 \%$ in 2018, can set itself as a viable alternative for internationally mobile skilled workers.

Provisions for skilled labor mobility within ASEAN principally revolve around mutual recognition arrangements (MRAs) that allow a worker's skills, experience, and accreditations to be recognized across ASEAN, permitting them to work outside their home countries. However, MRAs only cover eight professions (accounting, architecture, dentistry, engineering, medicine, nursing, surveying, and tourism), which account for roughly $5 \%$ of employment in ASEAN countries (Batalova et al. 2017). There is a large fraction of internationally mobile skilled workers in vocational occupations - from dental hygienists to specialized mechanics, and electrical technicians to construction workers. An effective framework for skills mobility must include those workers.

Even in the eight professions covered by MRAs, several technical and political barriers - both national and regional-impede professionals from moving and practicing their professions in other ASEAN countries (Papademetriou et al. 2015). For Cambodia, Thailand, Myanmar, and the Lao PDR, companies must demonstrate that there will be a transfer of knowledge to local employees, and that foreign employees will eventually be replaced by locals; in Indonesia, companies must prove that the position cannot be filled by local employees; in the Philippines, foreigners are constitutionally barred from certain occupations (DS\&A 2016).

Although there is substantial variation in standards across MRAs, some set the bar quite high. For example, an engineer must first hold a license to practice in their own country and have at least seven years' work experience after graduation. Only then can they apply for review to the ASEAN Chartered Professional Engineers Coordinating Committee and, if successful, work in other ASEAN countries as a "Registered Foreign Professional Engineer" (DS\&A 2016).

Stringent standards for the transferability and recognition of education and training are a leading obstacle to both talent flows and talent utilization. If their qualifications are not recognized by the host country, skilled migrants take up jobs that do not utilize or that underutilize their skills, leading to what economists call "brain waste." In the US, for example, nearly 2 million immigrants with college degrees were out of work or in low-skilled jobs in 2015 , thus missing out on more than $\$ 39$ billion in wages, and costing the US government more than $\$ 10$ billion in taxes (Batalova et al. 2016). The lack of recognition of experience and skills acquired abroad can be a powerful disincentive to migrate, given that workers think their mobility will be a drawback rather than a launching pad for their career. 
Chapter 8 provides the example of Indonesian nurse candidates in Japan, who are often treated by hospitals as "nurses' assistants" and assigned as careworkers despite being trained as nurses in Indonesia.

In addition to legislation barring foreigners from certain professions, restrictive labor policies in many ASEAN countries include immigration systems that severely limit work visas for foreign professionals, or do not provide for family reunification, or restrict spouses' ability to work. Even short-term work visas - which are useful for training, seasonal, or project-based employment - can be detrimental to talent flows because they discourage both migrant workers and employers from investing in on-the-job training most relevant to the host country labor market (Chiswick 2011).

Varying visa standards across the region do not incentivize employers to hire skilled workers from within ASEAN. A consequence of the federal structure in many ASEAN countries is that different states within the same country may have different documentation requirements. Citizens of ASEAN members do not enjoy priority status, and there is no streamlined immigration process compared with citizens of non-ASEAN countries. The result is that citizens of ASEAN member states may find it easier to emigrate outside the region, and it may be relatively easier for citizens of non-ASEAN countries to obtain a work visa in the region. A preferential work-based immigration system would allow ASEAN citizens to gain access to more intraregional career opportunities, which would encourage them to remain within the region. It would also offer employers access to a larger and more diverse local talent pool, which could be tapped with minimal interference (EY 2015).

The portability of social security benefits is another challenge to talent flows in ASEAN, especially as it pertains to retirement income. Migrant workers may lose access in their home countries before they qualify for benefits in their host countries - due to nationality conditions or minimum residency requirements. Even once they fulfill residency requirements and start paying into the system, there may be minimum required contribution periods before they can enjoy full benefits; and even then, benefits may not be exportable, or exportable with significant reductions (Pasadilla 2011). It is necessary for ASEAN members to establish mechanisms, such as social security agreements, through which their social security systems can cooperate to remove restrictions and ensure portability.

Another obstacle is the lack of regional standards regulating various industries. The ASEAN aviation industry, for example, does not have common regulations for personnel licensing, training, safety and maintenance, flight operators, and air traffic management. Establishing common guidelines for industries across ASEAN could facilitate the growth of 
regional businesses and industries, build a larger and more qualified labor force, and promote interconnectivity (DS\&A 2016).

One final challenge relates to the significant cultural diversity that characterizes the ASEAN region. As shown in Figure 1.4, there are three main streams of intra-ASEAN migration: the Indonesia-Malaysia route and the Malaysia-Singapore route absorb about $16 \%$ of intra-ASEAN migration each; and the Cambodia, Lao PDR, and Myanmar into Thailand (i.e., TCLM) route absorbs about 55\% (ILO and ADB 2014). It is no coincidence that all three routes are established between countries that are geographically and culturally close. Language differences are a major barrier to the transferability of skills. Even though migrant workers now study English for years and often speak English at work- especially in STEM occupations - they may find themselves at a disadvantage in everyday life if they do not speak the local language. As seen in Chapter 8 , intensive language training, as well as training in cultural understanding, can ease migrant integration into their host communities.

Cultural differences are likely to be less and less of an impediment as urban development continues in the region, providing a more cosmopolitan environment and more services to residents. The presence of enclaves of migrants for the same host country can be an advantage in overcoming information asymmetries and provide a support system for newly arrived migrants, but enclaves can sometime constitute an obstacle to migrant integration into host countries by increasing their interaction costs with natives (Danzer and Yaman 2012). Although individual characteristics such as education and years since migration also play important roles in a migrant's level of integration, engaging with migrant communities through education, civic and cultural participation, and other services can create a vibrant exchange of ideas and stimulate growth.

\section{CONCLUSIONS}

The lack of granular, consistent data on global migration flows is a serious obstacle to understanding both what drives skilled migration and how it affects source and host countries. A potential consequence is that perceptions and speculation, rather than facts, end up driving the policy debate. A review of the economic literature on migration contributes in two ways: (i) it shows how the way we think about migration has evolved over time, both in academia and society, as our understanding of this complex phenomenon deepened; and (ii) key findings establish a factual basis for policy decisions. It is worth reiterating that the literature review here is not meant to be exhaustive and the studies cited are not 
necessarily the most prominent. But they are the most relevant to the ASEAN region.

Two economic models are very helpful in explaining why just a small fraction of inter-ASEAN migrants are high skilled. First, there is the O-ring theory of economic development (Kremer 1993), where high-skill workers complement each other and therefore maximize productivity as they work together and access high-quality equipment. And, second, Grogger and Hanson (2011) show that the larger the difference in earnings between source and host country for the same skill level, the more skilled migrants will be attracted (positive selection). This may help explain why the share of high-skilled intra-ASEAN migrants remains so low. Furthermore, migrants sort themselves across destinations by skill, based on the rewards-to-skill in different destinations (positive sorting), which explains why all migrants do not simply flock to the country that pays the highest wage. Note that this sorting process happens both within and between professions - in fact, the concept of "skilled worker" is a fluid one, and often applies to those profiles that are in high demand rather than those above a certain "skill threshold." For example, advanced economies with aging populations are equally eager to attract migrants who are engineers with advanced degrees and careworkers for the elderly. Therefore, the Global Commission on International Migration suggests leaving the traditional distinction between high-skill and low-skill workers behind and using the term "essential workers" instead (GCIM 2005).

For decades, skilled emigration from economically depressed areas has been viewed as detrimental to the source country. The most common argument is that skilled workers enjoy a public subsidy for their education, and when they begin to contribute back to society they do so in another country. However, skilled emigration is only the proximate cause of this loss. The ultimate causes are the inefficiencies caused by government policies and other socioeconomic conditions in the source country.

A large body of literature debunks the negative perceptions of skilled emigration: that (i) it depletes human capital in the sending country, when evidence shows that prospective migration increases the stock of human capital net of migration; that (ii) skilled migrants remit less, when evidence shows they remit significantly more; and that (iii) skilled migrants sever ties with their home countries, when diaspora networks have historically provided foreign direct investment, access to markets, technology, and expertise. This is why there have been calls to stop referring to the phenomenon as a "brain drain," which has negative connotations, in favor of a more neutral or even positive expression such as "skill flow" (Clemens 2009) or "brain circulation." In fact, as mentioned above, source countries do not need their skilled emigrants to return in order to benefit from their expertise. 
Equally simplistic is the notion of "brain gain" associated with receiving countries. While early studies focused only on the social benefit of "free" human capital for the host economy, there is evidence that native workers who compete directly with foreign migrants can suffer a decrease in wages, and even be crowded out of sectors where competition with foreign workers is particularly intense. The magnitude of this effect depends on the degree of substitutability between migrant workers and foreign workers, which is likely to vary by sector. But it is also based on migrant characteristics such as country of origin, country of education, and years since migration, among others. Ottaviano and Peri (2005), for example, found that in the US foreign-born workers within a skill group are not perfect substitutes for native workers, and that foreign-born college graduates are the hardest to substitute with US-born college graduates. Therefore, we have a worstcase scenario of perfect substitutability between migrant and native skilled labor, and a best-case scenario in which foreign and native skilled workers complement each other - where the productivity boost results in a wage increase - which is what Ottaviano and Peri found for skilled workers in the US. In a world where employers are increasingly dependent on very specialized, unique skills - especially in STEM fields - the latter scenario becomes increasingly plausible. Even the so-called "crowding out effect" could be interpreted as native workers responding to incentives in the medium to long term and moving into professions where they can fully exploit their native advantage.

The breakdown of the Human Capital Index shows that optimizing a country's long-term human capital potential is a complex process that involves increasing educational attainment in the population (capacity), active participation in the workforce (deployment), continued upskilling and reskilling of the current workforce (development), and the use of advanced, specialized skills at work (know-how). Therefore, while an influx of skilled labor can help the host country build its human capital, deterring the outflow of skilled workers does not necessarily help the source country.

Numerous obstacles still block skills mobility in the region. Existing MRAs cover just a small fraction of internationally mobile skilled workers. And there remains a lack of political and public will in Southeast Asia to advance mobility even for this small group. Employers must go to great lengths to justify hiring foreign workers, and there is no preferential work-based immigration system for ASEAN citizens: visa applicants face lengthy procedures in which even states within the same country may have different documentation requirements. Workers who manage to move may lose access to social security benefits in their home countries before qualifying for benefits in their host countries. And the benefits earned in their host countries may not be exportable, or exportable with significant 
reductions. Finally, the remarkable cultural and linguistic diversity of the region means adequate language and cultural training must be provided to would-be migrants to ease integration in the host country.

Ultimately, achieving the goal of real brain circulation in the region may require some "thinking outside the box." The conventional approach has been based mainly on reciprocity and mutual recognition. Reciprocity means that citizens of country A are given the opportunity to practice their profession in country B if country A offers the same privilege to citizens of country B. Mutual recognition refers to the reciprocal acceptance of measures applied in both countries. Suppose country A and country B adopt different standards to achieve the same quality of training-without an agreement, professionals from one country wanting to work in the other country need to pay two fixed costs (one associated with the standard in country A and another with the standard in B). However, if countries A and $\mathrm{B}$ recognize their standards (mutual recognition) as equivalent, professionals will be able to operate in both markets, paying only one fixed cost of entry.

The main challenge of attempting to foster skills mobility through reciprocity and mutual recognition in such a diverse group of countries is that the desired level of standards may differ across countries, and "setting domestic standards at a level that enhances the case for foreign recognition may lead to standards that are inappropriately 'high' from a domestic perspective" (Mattoo and Mishra 2009). That would be a problem, for example, if education and training institutions struggle to comply with the high standards or divert scarce resources to foreign recognition rather than serving the local market.

An additional concern is heterogeneity of standards within source countries. For example, it is not uncommon for developing countries to have poor-quality education and training providers coexist with internationally competitive ones, often concentrated in the capital region. The difficulty in observing the true competence levels of incoming professionals is another reason why host countries are reluctant to remove technical barriers to skills mobility.

One solution could be creating a literal "double standard" - one at a level that creates a credible case for foreign recognition, with the other at a level appropriate to domestic needs. For example, the Philippines may train nurses who are going to work abroad to a higher (or different) standard than those who are going to work domestically (Mattoo 2018). The domestic population, especially in underserved areas, would benefit because professionals trained to the "local" standard would be less likely to emigrate. At the same time, professionals who want to work abroad would train under the "export-oriented" standard, which would target specific export markets (Mattoo and Mishra 2009). Institutions could self-select 
into the domestic or export-oriented standard, for example through an accreditation system, and pathways and equivalencies could be developed to give professionals the flexibility to move from one standard to another. Alternatively, the system could be examination-based. The key element would be the source country providing quality assurance through premigration screening and selection of would-be migrants.

The system described above may not necessarily be desirable for ASEAN. But it is an example of a more flexible approach where concerns of both source and host countries are addressed. In Chapter 10, we discuss how the Fourth Industrial Revolution will revolutionize work and worker mobility, but it is already clear that novel and flexible policy solutions will be required to rise to the challenge.

\section{NOTES}

* I thank Kathleen Farrin and Rana Hasan for peer reviewing the chapter, and Donald Jay Bertulfo for excellent research assistance. This chapter has benefited from conversations with Jesus Felipe, Aditya Mattoo, and Dean Yang.

1. Author's calculations based on data from United Nations (2015).

2. The opposite scenario would be positive selection, i.e., migrants are more skilled than those who remain.

3. Points-based immigration systems are used in Australia; Austria; Canada; Denmark; Germany; Hong Kong, China; Japan; New Zealand; the Republic of Korea; and the UK. In the US, the two main political parties have proposed their own versions of legislation that would shift the country from a predominantly "targeted occupation system"-in which employers petition for a visa on behalf of an applicant and must demonstrate that the applicant has skills that are scarce in the host country (Chiswick 2011) - to a points-based immigration system.

4. An emigrant is someone who leaves their place of residence or country to live elsewhere, whereas an immigrant is a person who comes to a country to take up permanent residence. Therefore, an individual is an emigrant with respect to their place of origin (source country), and an immigrant with respect to their destination (host territory).

5. The question asked was: "Ideally, if you had the opportunity, would you like to move permanently or temporarily to another country, or would you prefer to continue living in this country?" It is part of the core questionnaire. For a detailed discussion of the Gallup World Poll questions, see Gallup (2008).

6. The economies of Indonesia, Malaysia, the Philippines, Thailand, and Viet Nam are collectively referred to as "tiger cub economies" because they chose the same exportdriven model of development that transformed the original four Asian Tigers (Hong Kong, China; the Republic of Korea; Singapore; and Taipei,China) into high-income economies within one generation.

7. The Arab states bordering the Persian Gulf, often abbreviated as the "Gulf countries," include Bahrain, Iraq, Kuwait, Oman, Qatar, Saudi Arabia, and the United Arab Emirates (UAE).

8. The six occupation groups are: (i) laborers, farm workers, and low-skilled service workers; (ii) operatives and craft workers; (iii) clerical workers; (iv) sales workers; (v) managers; and (vi) professional and technical workers.

9. For a thorough discussion of the theoretical literature on migration and relevant empirical tests, see Massey et al. (2005). 
10. For an extended discussion of the studies that followed Borjas (1987), see Hanson (2010).

11. All immigration numbers come from UN (2015). Average monthly wages are International Labour Organization (ILO) estimates based on 2013 labor force surveys from ILO and ADB (2014, Tables 1-4, p. 8).

12. The third industrial revolution took place in the latter part of the 20th century and involved the ongoing automation of several manufacturing processes, as well as the establishment of global production networks aided by trade liberalization and lower transport costs. This led to lower-cost labor in developing economies becoming a suitable alternative to more mechanized production. The process was disruptive to the existing manufacturing landscape in many advanced economies, whereas many developing economies, particularly in East Asia, began to quickly catch up to the level of economic development of advanced economies.

13. Fan and Stark (2007) use this expression to refer to the branch of the literature according to which "higher prospective returns to human capital in a foreign country impinge favorably on human capital formation decisions at home." See, for example, Stark et al. (1997, 1998), Mountford (1997), and Stark and Wang (2002).

14. The law of diminishing marginal product states that while increasing the supply of one factor of production (e.g., high-skill labor) and keeping others at the same level may initially increase output, further increases in that factor will have a limited effect and will eventually have no effect, or a negative effect, on output.

\section{REFERENCES}

Abarcar, Paolo and Caroline Theoharides. (2017). "The International Migration of Healthcare Professionals and the Supply of Educated Individuals Left Behind." Draft paper.

Alesina, Alberto, Armando Miano, and Stefanie Stantcheva. (2018). "Immigration and Redistribution." Working paper.

ASEAN. (2016). Master Plan on ASEAN Connectivity 2025. Jakarta: ASEAN Secretariat.

Batalova, Jeanne, Michael Fix, and James D. Bachmeier. (2016). Untapped Talent: The Costs of Brain Waste among Highly Skilled Immigrants in the United States. Washington, DC: Migration Policy Institute, New American Economy, and World Education Services.

Batalova, Jeanne, Andriy Shymonyak, and Guntur Sugiyarto. (2017). Firing Up Regional Brain Networks: The Promise of Brain Circulation in the ASEAN Economic Community. Manila: Asian Development Bank.

Bhagwati, Jagdish N. (1976). "Taxing the Brain Drain." Challenge 19(3): 34-8.

Bhagwati, Jagdish N. and Koichi Hamada. (1974). "The Brain Drain, International Integration of Markets for Professionals and Unemployment: A Theoretical Analysis." Journal of Development Economics 1(1): 19-42.

Bollard, Albert, David McKenzie, Melanie Morten, and Hillel Rapoport. (2011). "Remittances and the Brain Drain Revisited: The Microdata Show that More Educated Migrants Remit More." World Bank Economic Review 25(1): 132-156.

Borjas, George J. (1987). "Self-Selection and the Earnings of Immigrants." American Economic Review 77(4): 531-53.

Borjas, George J. (2003). "The Labor Demand Curve is Downward Sloping: Reexamining the Impact of Immigration on the Labor Market." Quarterly Journal of Economics 118(4): 1335-74. 
Borjas, George J. (2005). "The Labor Market Impact of High-skill Immigration." Working Paper No. 11217. National Bureau of Economic Research (NBER).

Bueno, Tom. (2013). "Singapore's Immigration Struggles.” The Diplomat. July 28. https://thediplomat.com/2013/07/singapores-immigration-struggles/.

Card, David. (2001). "Immigrant Inflows, Native Outflows, and the Local Labor Market Impacts of Higher Immigration.” Journal of Labor Economics 19(1): 22-64.

Chand, Satish and Michael Clemens. (2008). "Skilled Emigration and Skill Creation: A Quasi-Experiment." Working Paper No. 152. Center for Global Development.

Chellaraj, Gnanaraj, Keith E. Maskus, and Aaditya Mattoo. (2008). "The Contribution of International Graduate Students to US Innovation." Review of International Economics 16(3): 444-62.

Chiswick, Barry R. (2011). "Immigration: High Skilled vs. Low Skilled Labor?" Policy Paper No. 28. Forschungsinstitut zur Zukunft der Arbeit (IZA).

Clemens, Michael. (2009). "Skill Flow: A Fundamental Reconsideration of SkilledWorker Mobility and Development." Working Paper No. 180. Center for Global Development.

Danzer, Alexander M. and Firat Yaman. (2012). "Do Ethnic Enclaves Impede Immigrants' Integration? Evidence from a Quasi-Experimental Social-Interaction Approach.” German Socio-Economic Panel Study (SOEP) No. 519. Berlin: Deutsches Institut für Wirtschaftsforschung (DIW).

Davie, Sandra. (2014). "Singapore May Rue Fall in Foreign Student Numbers." Straits Times. October 2. https://www.straitstimes.com/opinion/singapore-may-rue -fall-in-foreign-student-numbers.

Desai, Mihir A., Devesh Kapur, John McHale, and Keith Rogers. (2009). "The Fiscal Impact of High-skilled Emigration: Flows of Indians to the US." Journal of Development Economics 88(1): 32-44.

Dezan Shira \& Associates (DS\&A). (2016). "Labor Mobility in ASEAN: Current Commitments and Future Limitations." ASEAN Briefing. https://www.asean briefing.com/news/2016/05/13/asean-labor-mobility.html.

Dinkelman, Taryn and Martine Mariotti. (2016). "The Long-Run Effects of Labor Migration on Human Capital Formation in Communities of Origin." American Economic Journal: Applied Economics 8(4): 1-35.

Docquier, Frédéric, Giovanni Peri, and Ilse Ruyssen. (2014). "The Cross-country Determinants of Potential and Actual Migration." International Migration Review 48(S1): S37-S99.

Ernst \& Young (EY). (2015). Trade Secrets: The Last Mile Toward 2015 and Beyond-Toward Intra-ASEAN Labor Mobility. Singapore: EYGM Limited.

Faini, Riccardo. (2007). "Remittances and the Brain Drain: Do More Skilled Migrants Remit More?" World Bank Economic Review 21(2): 177-91.

Fairlie, Robert, Arnobio Morelix, and Inara Tareque. (2017). "The 2017 Kauffman Index of Startup Activity: National Trends." Ewing Marion Kauffman Foundation.

Felipe, Jesus. (2010). Inclusive Growth, Full Employment, and Structural Change: Implications and Policies for Developing Asia. London/Manila: Anthem Press India and Asian Development Bank.

Friedberg, Rachel. (2001). "The Impact of Mass Migration on the Israeli Labor Market." Quarterly Journal of Economics 116(4): 1373-408.

Gallup. (2008). World Poll Questions. Washington, DC: Gallup. http://media. gallup.com/dataviz/www/WP_Questions_WHITE.pdf.

Global Commission on International Migration. (2005). Migration in an Interconnected World: New Directions for Action. Geneva: GCIM. 
Goeltom, Miranda S. (2007). Essays in Macroeconomic Policy: The Indonesian Experience. Jakarta: PT Gramedia Pustaka Utama.

Grogger, Jeffrey and Gordon H. Hanson. (2011). "Income maximization and the Selection and Sorting of International Migrants." Journal of Development Economics 95(1): 42-57.

Grubel, Herbert and Anthony Scott. (1966). "The Immigration of Scientists and Engineers to the United States, 1949-61." Journal of Political Economy 74(4): 368-78.

Hanson, Gordon H. (2010). "International Migration and Development." In Equity and Growth in a Globalizing World, edited by Ravi Kanbur and Michael Spence, 229-62. Washington, DC: World Bank.

International Labour Organization (2015). Migration: Closing the Gap between Perceptions and True Facts. Geneva: ILO. http://www.ilo.org/global/about-the-ilo/ newsroom/news/WCMS_364595/lang--en/index.htm.

International Labour Organization and Asian Development Bank. (2014). ASEAN Community 2015: Managing Integration for Better Jobs and Shared Prosperity. Bangkok: ILO and ADB.

Khanna, Gaurav and Nicolas Morales. (2017). "The IT Boom and other Unintended Consequences of Chasing the American Dream." Working paper.

Kremer, Michael. (1993). "The O-Ring Theory of Economic Development." Quarterly Journal of Economics 108(3): 551-75.

Kuznetsov, Yevgeny and Charles Sabel. (2006). "International Migration of Talent, Diaspora Networks, and Development: Overview of Main Issues.” In Diaspora Networks and the International Migration of Skills: How Countries Can Draw on their Talent Abroad, edited by Yevgeny Kuznetsov, 3-19. Washington, DC: International Bank for Reconstruction and Development and World Bank.

Massey, Douglas S. et al. (2005). Worlds in Motion: Understanding International Migration at the End of the Millennium. Oxford: Oxford University Press.

Mattoo, Aaditya. (2018). "Services Globalization in an Age of Insecurity: Rethinking Trade Cooperation." Working paper.

Mattoo, Aditya and Deepak Mishra. (2009). "Foreign Professionals in the United States: Regulatory Impediments to Trade." Journal of International Economic Law 12(2): 435-56.

Mountford, Andrew. (1997). "Can a Brain Drain Be Good for Growth in the Source Economy?” Journal of Development Economics 53(2): 287-303.

Niimi, Yoko, Caglar Ozden, and Maurice Schiff. (2008). "Remittances and the Brain Drain: Skilled Migrants Do Remit Less.” Discussion Paper No. 3393. Forschungsinstitut zur Zukunft der Arbeit (IZA).

Ottaviano, Gianmarco I.P. and Giovanni Peri. (2005). "Rethinking the Gains from Immigration: Theory and Evidence from the US." Working Paper No. 11672. National Bureau of Economic Research (NBER).

Papademetriou, Demetrios G., Guntur Sugiyarto, Dovelyn Rannveig Mendoza, and Brian Salant. (2015). Achieving Skill Mobility in the ASEAN Economic Community: Challenges, Opportunities, and Policy Implications. Manila: Asian Development Bank.

Parpart, Erich. (2016). "Skill Shortage: Upbeat Talk about Skilled Labour Mobility in the ASEAN Economic Community Has Not Yet Been Translated into Action." Bangkok Post, October 3.

Pasadilla, Gloria O. (2011). "Social Security and Labor Migration in ASEAN." Research Policy Brief No. 34. Tokyo: Asian Development Bank Institute (ADBI). 
Regets, Mark C. (2001). "Research and Policy Issues in High-Skilled International Migration: A Perspective with Data from the United States." Discussion Paper No. 366. Forschungsinstitut zur Zukunft der Arbeit (IZA).

Roy, A.D. (1951). "Some Thoughts on the Distribution of Earnings." Oxford Economic Papers 3(2): 135-46.

Ruhs, Martin. (2016). Preparing for Increased Labour Mobility in ASEAN: Labour Markets, Immigration Policies and Migrant Rights. Bangkok: International Organization for Migration, Country Mission Thailand.

Seah, Kelvin and Ivan Png. (2018). "Time for Singapore Universities to Admit More International Students.” Today, January 29. https://www.todayonline.com/dailyfocus/education/time-singapore-universities-admit-more-international-students.

Shrestha, Slesh A. (2017). "No Man Left Behind: Effects of Emigration Prospects on Educational and Labour Outcomes of Non-migrants." Economic Journal 127(600): 495-521.

Stark, Oded, Christian Helmenstein, and Alexia Prskawetz. (1997). "A Brain Gain with a Brain Drain." Economics Letters 55(2): 227-34.

Stark, Oded, Christian Helmenstein, and Alexia Prskawetz. (1998). "Human Capital Depletion, Human Capital Formation, and Migration: A Blessing or a “Curse'?" Economics Letters 60(3): 363-67.

Stark, Oded and Yong Wang. (2002). "Inducing Human Capital Formation: Migration as a Substitute for Subsidies." Journal of Public Economics 86(1): $29-46$.

Stone, Richard. (1999). "Israel Hits Rich Seam in Ex-Soviet Immigrants.” Science 284(5416): 892-97.

Theoharides, Caroline. (2018). "Manila to Malaysia, Quezon to Qatar: International Migration and its Effects on Origin-Country Human Capital." Journal of Human Resources 53(4): 1022-49.

United Nations. (2015). Trends in International Migrant Stock: The 2015 Revision. New York: United Nations.

World Economic Forum. (2016). Human Capital Outlook: Association of Southeast Asian Nations (ASEAN). Regional Community Briefing (World Economic Forum). Geneva: World Economic Forum. https://www.weforum.org/reports/ human-capital-outlook-association-of-southeast-asian-nations-asean/.

Yang, Dean. (2008). "International Migration, Remittances, and Household Investment: Evidence from Philippine Migrants' Exchange Rate Shocks." Economic Journal 118(2): 591-630.

Zahidi, Saadia, Leopold Till, and Vesselina Ratcheva. (2017). The Global Human Capital Report 2017: Preparing People for the Future of Work. Insight Report (World Economic Forum). Geneva: World Economic Forum. https://www. weforum.org/reports/the-global-human-capital-report-2017. 